\title{
The history of Taxus baccata L. in the Wierzchlas (N Poland) on the basis of palynological research
}

\author{
Agnieszka M. Noryśkiewicz \\ Institute of Archaeology, Nicolaus Copernicus University, Szosa Bydgoska 44/48, 87-100 Toruń, Poland; \\ e-mail: agnieszka.noryskiewicz@umk.pl
}

Received: 20 April 2017/Accepted: 12 June 2017

\begin{abstract}
Wierzchlas forest reserve forms the biggest natural stand of the Taxus baccata in Poland. The pollen analysis of biogenic sediments from Mukrz Lake registers the history of the plant cover of area surrounding Mukrz Lake starting from Vistulian Late Glacial period through the Holocene until the contemporary times and indicates that Taxus baccata may be native from the beginning of the Subboreal to the present time. Additional research was made because of the small representation of Taxus in the fossil samples. The fossil spectra were supplemented with the results of surface samples taken from the bottom of the lake and from the forest, together with the results of annual pollen deposition. The presence of yew pollen grains in surface materials from the reserve in Wierzchlas depends, thus, on both the distance between the sample taken and a male yew individual as well as the stand density. The comparison of the surface spectra from different habitats of this reserve (lake, forest floor and peatbog) and material from Tauber's traps reflected a large discrepancy in the representation of yew. These differences are related to both the habitat from which the material originated, and also to the distance between the sampling point and the location of a male yew tree.
\end{abstract}

Key words: history of Taxus baccata L., pollen analysis, surface samples, modern annual pollen deposition, northern Poland, Wierzchlas Reserve.

\section{Introduction}

The study area is located in northern Poland (Fig. 1), app. $40 \mathrm{~km}$ to the west of the Vistula River. The choice of the location to conduct palynological research was not coincidental. The eastern limit of natural occurrence of yew runs across the Poland (Zając A. \& Zając M. 2001). Wierzchlas forest reserve contains the biggest natural stand of common yew (Taxus baccata) in Poland. The reserve lies in the south Pomeranian Lake District in the south-eastern area of a well-stocked forest complex of Tuchola Forest. It is the oldest and at the same time one of the most valuable protected forest areas in Poland. Nearly all types of trees and shrubs growing wild in the Polish Lowland occur in this area (Boiński 1997). The reserve, which is the remains of a former Tuchola Primeval Forest, currently is a multispecies forest with the yew making the lower layer.

The first aim of a palynological research that was carried out in the reserve was to provide an explanation to the Holocene history of yew in the context of a development of postglacial vegetation within this area (Noryśkiewicz 1997, 2001). The research originally focused on the analysis of biogenic sediments from Mukrz Lake. However, in order to explain the small representation of pollen grains of Taxus, the analyses were supplemented with the results of the surface samples of the lake sediment and of forest litter surface samples taken from various habitats in the reserve and also the results of annual pollen deposition measured by Tauber traps. 


\section{Material and methods}

\subsection{Lake sediment}

The pollen analysis of two profiles of biogenic sediments from Mukrz Lake $\left(\mathrm{M}_{\mathrm{I}}, \mathrm{M}_{\mathrm{II}}\right)$ and two profiles from peatbogs (W/Ol, W/Ot) were taken (Noryśkiewicz 2006) for analysis using the Livingstone probe modified by Więckowski (1970). All fossil cores were taken close to large stands of yew (Fig. 1) - now there are about 3 thousands yew-trees on the 18 hectare site. From the south the lake borders phytocoenosis where the yew occurs.

The samples from the bottom of Mukrz Lake (the surface samples of the lake sediment) were collected using a Kajak's tubular catcher. The material was obtained in the transect of three sites (A-B-C). The location of sites B and $\mathrm{C}$ corresponds with the location of profiles from the lake (Fig. 1).
Three different types of surface pollen samples were analysed in order to explain the small representation of Taxus in the fossil samples.

\subsection{Twelve samples of forest litter from various habitats from the reserve}

Eight samples were taken from the subcontinental dryground forest (Tilio-Carpinetum), two from ash-alder riverside carr (Circaeo-Alnetum), one from currant alder carr (Ribo nigri-Alnetum) and the last one from the peatbog with fibrous tussock sedge (Caricetum appropinquatae) (Fig. 2).

\subsection{Eighteen samples from the vicinity of the isolated yew}

The samples for pollen analyses were taken in the transect from under one male yew (Fig. 3), that was relatively isolated from other male trees of this species.

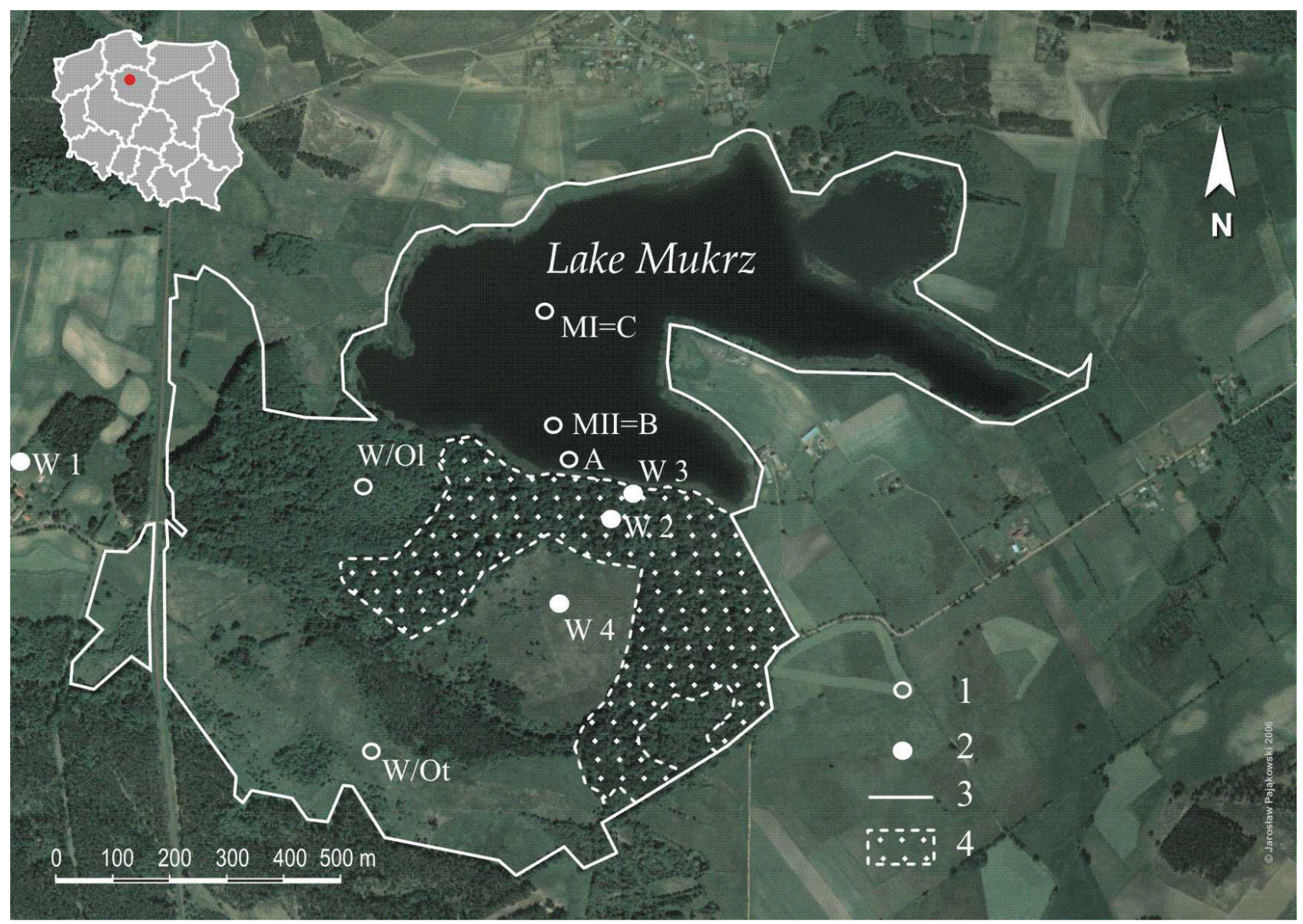

Figure 1. Wierzchlas; Location of the investigation area against the background of forests near Mukrz Lake: 1 - location of the profiles $\mathrm{M}_{\mathrm{I}}, \mathrm{M}_{\mathrm{II}}, \mathrm{W} / \mathrm{O} 1, \mathrm{~W} / \mathrm{Ot}$ and A, B, C; 2 - location of the pollen traps W1, W2, W3,W4; 3 - border of the reserve; 4 - border of the buffer zone, forest with yew (acc. Pająkowski, after Noryśkiewicz 2012) 


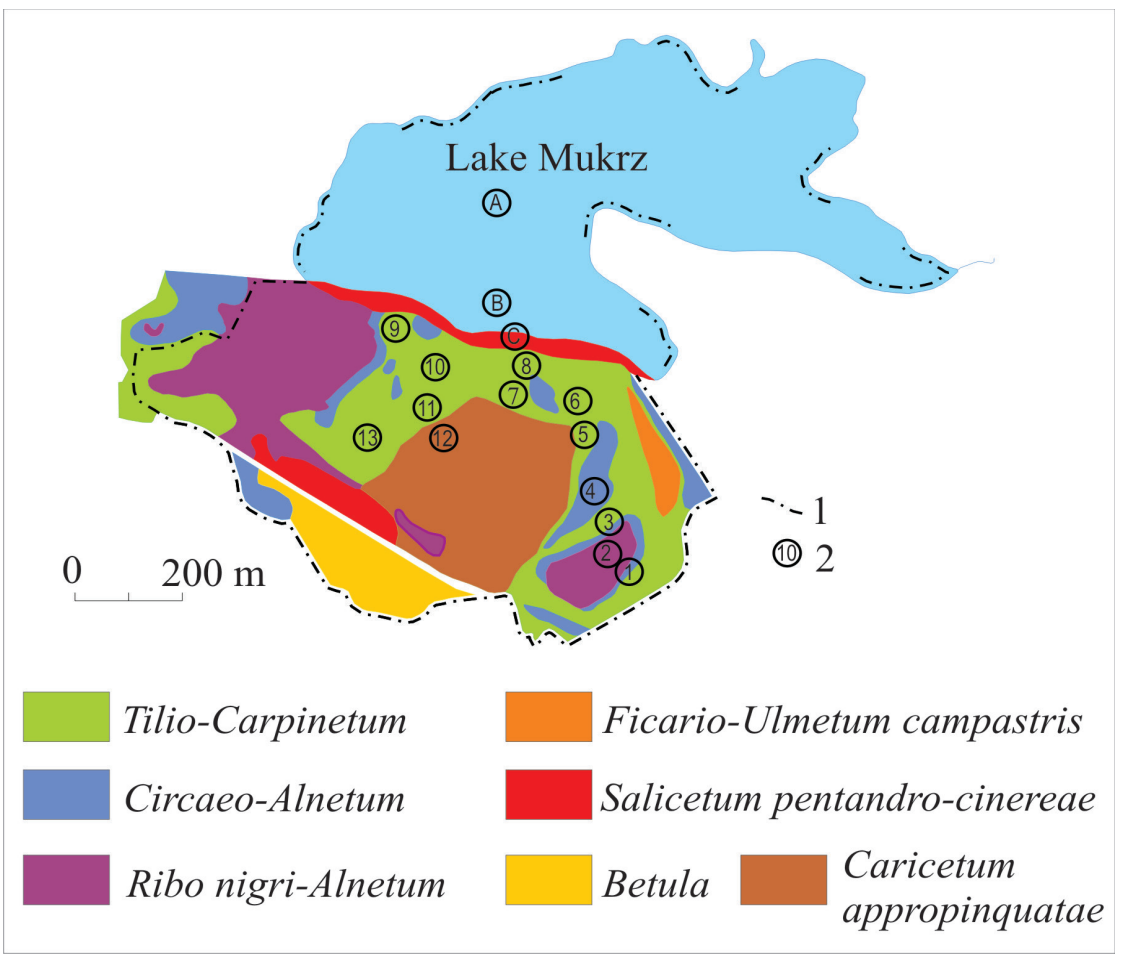

Figure 2. Wierzchlas; Plant associations of the Wierzchlas reserve (acc. Boinski 1997); 1 - border of the reserve; 2 - location of the surface samples

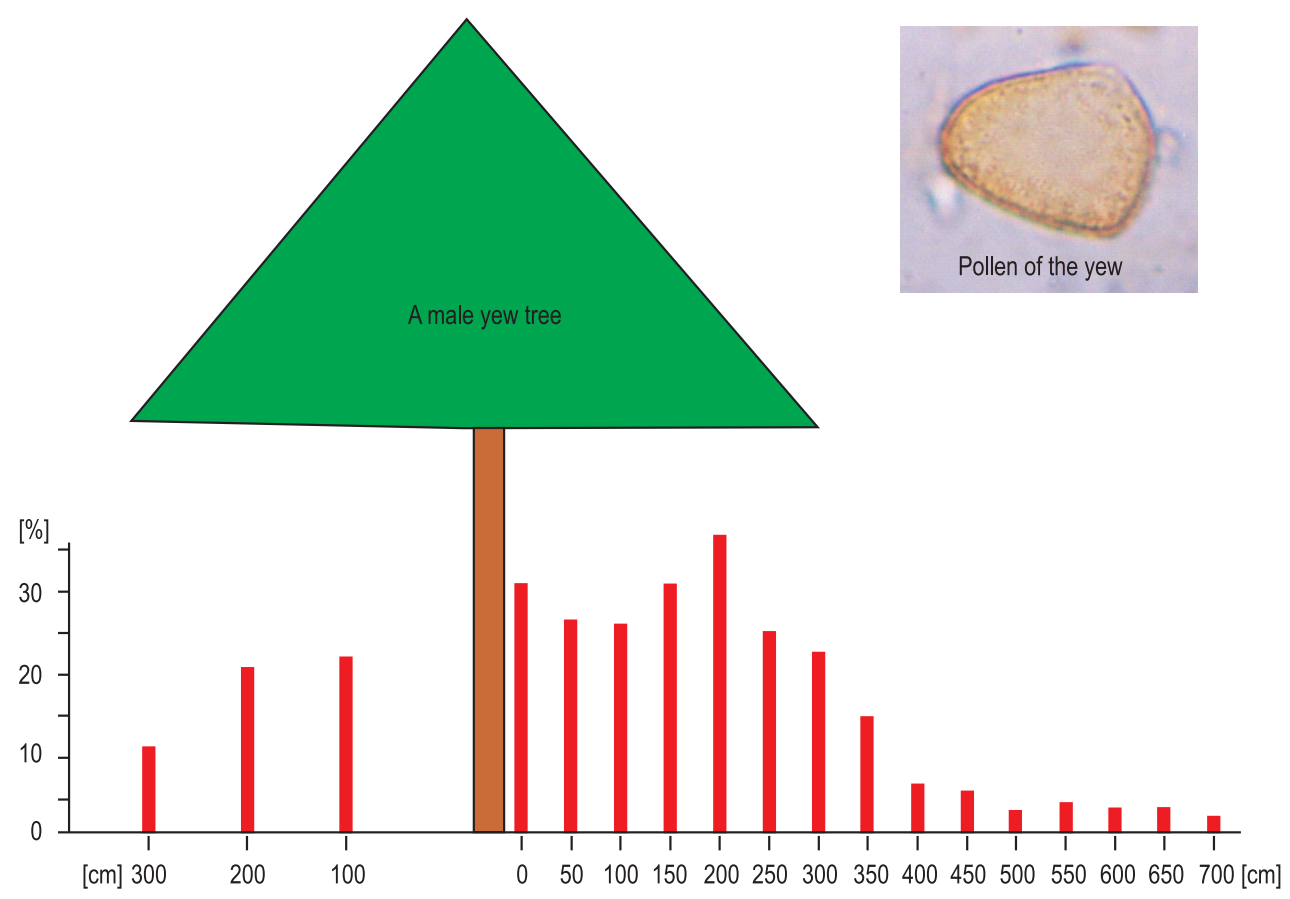

Figure 3. Wierzchlas; Location of the samples in the transect from under one male yew in the forest. and percentage participation of Taxus baccata pollen (site13 in Fig. 2) 


\subsection{Samples from Tauber traps}

Since 1997 (19 seasons) annual pollen rain has been monitored in accordance with Pollen Monitoring Programme recommendations (Hicks et. al 1996, www.pollentrapping. org). Four pollen traps are placed in a short transect in different types of vegetation (Fig. 1): W1 and W4 in the open area; W2 in the close-canopy mixed forest with a yew; W3 on the edge of the mixed humid (damp) forest near the lake. The pollen trap W1 was placed approx. $0.7 \mathrm{~km}$ away from the reserve, outside the tree cover in the vicinity of the farmlands and homestead garden. Three traps were placed within the reserve, representing a forested area, the forest edge and an open area. Trap W2 was situated in the yew forest under the dense forest canopy W3 at the forest edge, under the forest canopy, 4 meters south of the shore of the lake and W4, on the peat bog (tussock-sedge swamp) in the central part of the reserve (Fig. 1).

All samples for pollen analysis were processed following the guidelines proposed by Berglund and Ralska-Jasiewiczowa (1986). All pollen percentages were calculated on the basis of sum including trees and shrubs (AP) as well as dwarf shrubs and herb pollen (NAP), but excluding limnophytes, telmatophytes and sporophytes. Tablets contain-

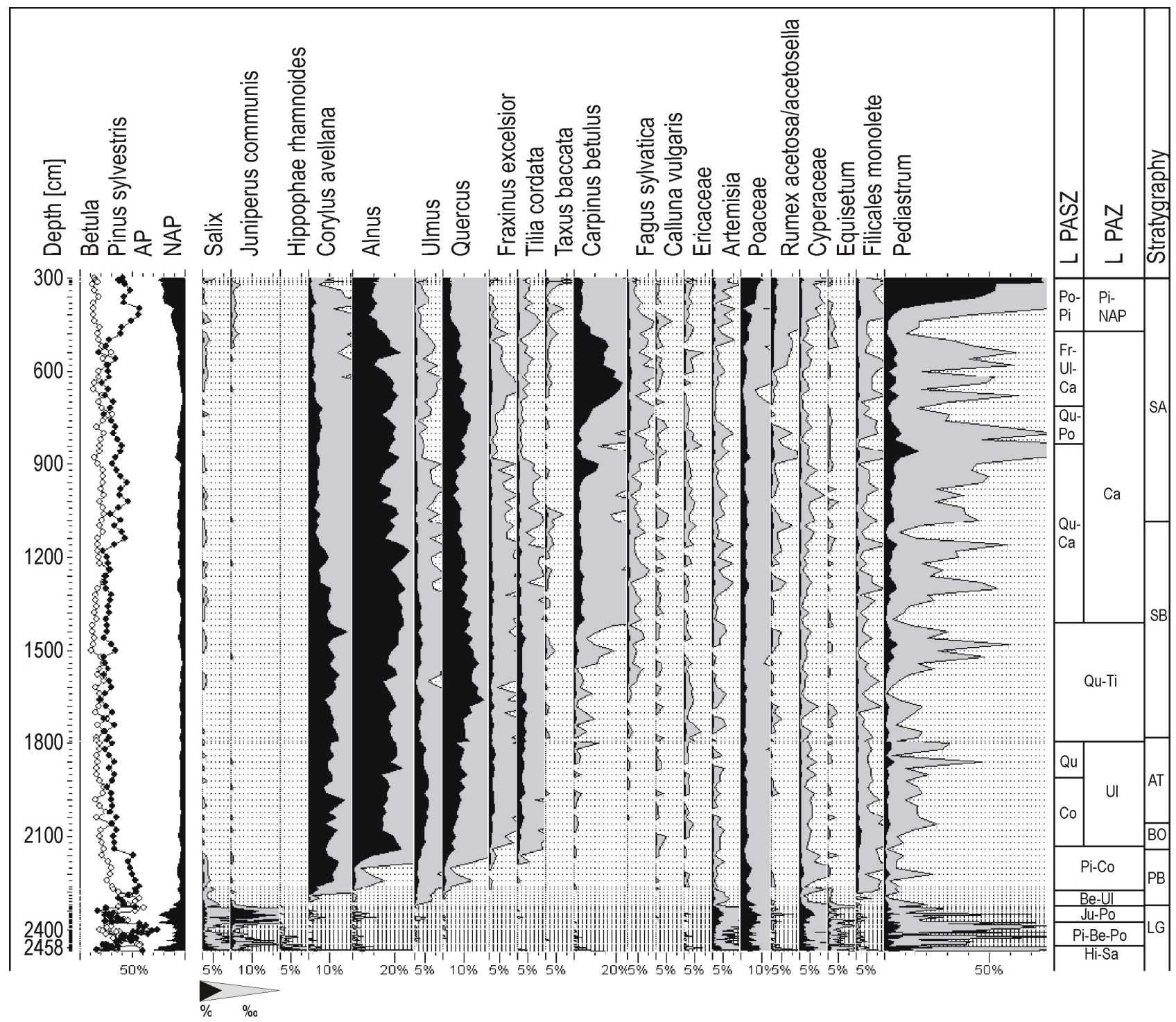

Figure 4. Wierzchlas; Mukrz Lake, profile M1, percentage pollen diagram of selected taxa; AP - Arboreal Pollen (trees and shrubs), NAP - Non Arboreal Pollen (draftshrubs and herbs), Be - Betula, Ca - Carpinus, Co - Corylus, Fr - Fraxinus, Hi - Hippophaё, Ju - Juniperus, Pi - Pinus, Po - Poaceae, Qu - Quercus, Sa - Salix, Ti - Tilia, Ul - Ulmus, SA - Subatlantic, SB - Subboreal, AT - Atlantic, BO - Boreal, PB - Preboreal, LG - Late Glacial 
ing Lycopodium spores were added before any laboratory treatment, to enable the calculation of pollen concentration and influx (Stockmarr 1971). The pollen trap samples were centrifuged and then prepared in a comparable way to the fossil and surface samples (Hicks et al. 1996).

\section{Results and discussion}

\subsection{Pollen analysis of fossil samples}

Pollen analysis of biogenic sediments records the vegetation history of the Mukrz Lake surroundings, starting from late Vistulian glacial period through the Holocene until the contemporary times (Noryśkiewicz 2006). The successful location of the lake cores under research (central and shore area of the water body) made it possible to analyse both the history of regional and local vegetation as well as to follow the history of Mukrz Lake (Tobolski 2002).

The oldest fragment (Fig. 4) covers the transition of the Oldest Dryas and Bölling and characterises the assemblage of shrub tundra mainly with Hippophae rhamnoides and Salix (W1 - Hi-Sa L PAZ, Fig. 4). In the shore profile $\left(\mathrm{M}_{\mathrm{II}}\right)$ this zone represents the layer of peat, which reflects the melting character of this water body (Noryśkiewicz 2006). Next zone (W2 - Pi-Be-Po L PAZ, Fig. 4) corresponds to the Alleröd-Bölling complex. The youngest part of the late glacial period covers the cooling of the Younger Dryas, that is strongly marked, which resulted in the recession of the pine forest and the renewed widespread of the park tundra, mainly in the form of Juniperus scrubs (W3 - JuPo L PAZ, Fig. 4). At the beginning of the Holocene in the region of Mukrz Lake, birch-pine forests spread. With the improvement of climatic conditions, high-growing, multispecies forest became dense. In the climatic optimum we can observe a considerable transformation of vegetation cover. A noticeable increase in the participation of deciduous trees such as elm (Ulmus), oak (Quercus), ash (Fraxinus) and linden (Tilia) takes place. Latest of all, i.e. in the Subboreal period, there appear trees such as the hornbeam (Carpinus betulus), the beech (Fagus sylvatica) and the yew. Single sporomorphs of Taxus appear simultaneously with the first Carpinus and Fagus pollen grains.

A continuous curve of the yew starts after the last hornbeam maximum. The biggest participation of hornbeam, is connected with the forest regeneration phase relating to the Migration Period in archaeological divisions.

The maximal participation of the yew was $1.6 \%$ in the main profile (Fig. 4), and 3.1\% in the Mukrz II profile and $0.5 \%$ in the peatbog profile (taken from reserve) (Noryśkiewicz 2006). These relatively high values could reflected a documented selective protection of the yew and its artificial planting in Wierzchlas. Although today the yew trees in this area are well represented in the surface pollen samples, Taxus baccata pollen was represented in very small numbers in this fossil samples (exceeding 1\% in only two pollen spectra).

In order to examine the participation of yew pollen in the bottom part of Mukrz Lake samples for pollen analysis were taken from upper, $25 \mathrm{~cm}$ semi-liquid, part of the

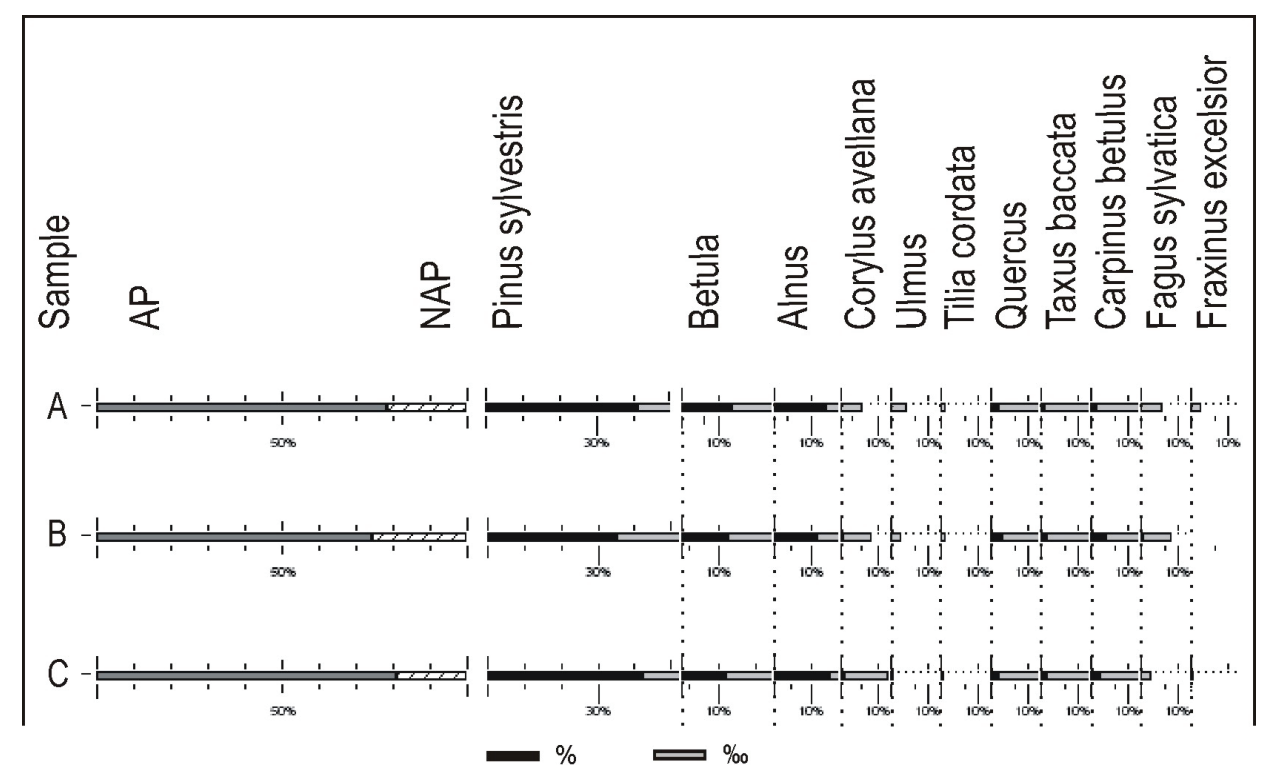

Figure 5. Wierzchlas; Mukrz Lake, profiles A, B, C, percentage pollen diagrams for the upper, semiliquid part of the lake sediments. Explanation of letters as in Fig. 1 
lake sediment. The pollen spectra from these sites (A, B, C; Fig. 1) also low frequencies of Taxus, i.e. 1.5\%, 2.1\% and $1.8 \%$ respectively (Fig. 5 ).

\subsection{The surface samples}

Comparison of surface spectra from different habitats reveals that there is a large discrepancy in the representation of yew (Fig. 6). The highest percentage of yew is found in the samples originating from the Tilio-Carpinetum assemblage (primarily samples 3, 5 but also 6, 7, 8, 9, 10 and 11). The lowest percentage is noted in alder forests (samples 1, 2 and 4) and on the peatbog (sample 12). The lowest results correspond to the absence of the yew in these plant assemblages. The differences in the yew percentage, which appear within the Tilio-Carpinetum assemblage, reflect the distance from the male yew. Large quantities of Taxus pollen were recorded only in surface samples collected close to the male yew (samples number 3 and 5).

This conclusion is confirmed by the research carried out in Wierzchlas on the dispersion of yew pollen grains. Samples were taken in the section from under one individual male yew (sample 13, Figs. 2 and 3), that was relatively isolated from other male trees of this species. High frequencies of yew pollen grains are found in the spectra from samples taken directly from under the treecrown $24.1-35 \%$ (within 3-meter range) and the frequency decreases gradually with the increased distance $5.7-1.9 \%$ (Figs. 3 and 7).

A considerable density of the trees also limits pollen grains spreading outside the forest boundaries. The phytosociological survey of the surface of $200 \mathrm{~m}^{2}$ documents that around the tree under research only yew, elm, linden, hornbeam and maple grow. It turns out that pollen grains of the remaining trees come from long distant transport.

The pine pollen originates from further transportation and does not react against the local presence of the pollen yew (Fig. 7). The birch, which does not appear in the survey area, but numerous individuals grow at a distance of app. $100 \mathrm{~m}$ in the peatbog and forest edge and its considerable concentration is located about $200 \mathrm{~m}$ away (Fig. 2), reacts markedly to the yew presence fluctuations. The percentage participation of the birch and the yew pollen shows an inverse relationship (the increase of one causes a decrease of the other one; Fig. 7).

\subsection{Modern annual pollen deposition}

In the pollen trap W1 located in the open area barely a kilometre from a dense stand of yew, and about 150 meters from a single male yew shows a very low representation, which is comparable with the samples from the lake. Considering that the isolated yew blossomed plentifully in all seasons, the influx values seem disproportionately low.

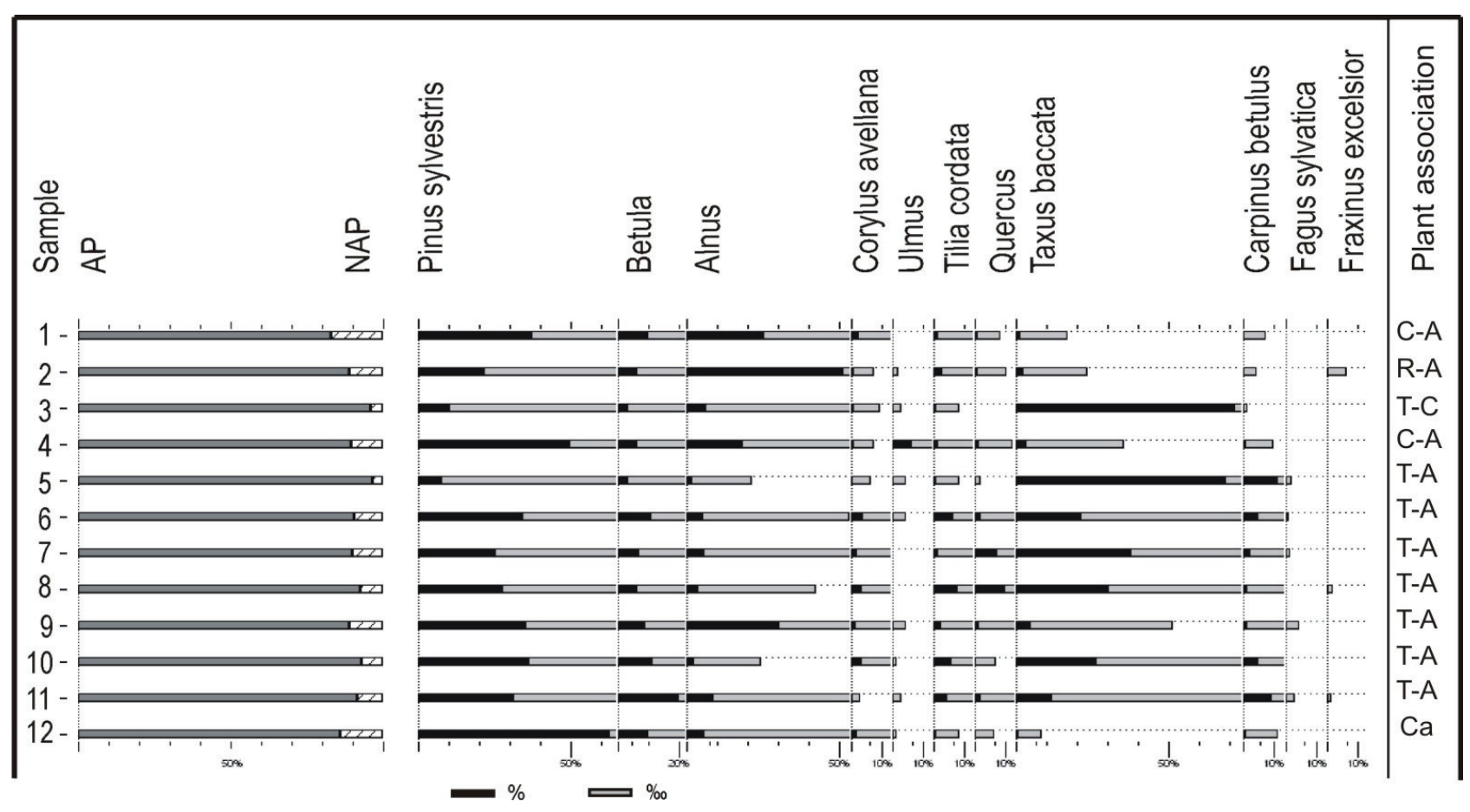

Figure 6. Wierzchlas; Surface samples taken from the litter, percentage pollen diagram selected major taxa. Location of the samples as in Fig. 2; C-A - Circaeo-Alnetum, R-A - Ribo nigri-Alnetum; T-C - Tilio-Carpinetum, Ca - Caricetum appropinquatae 


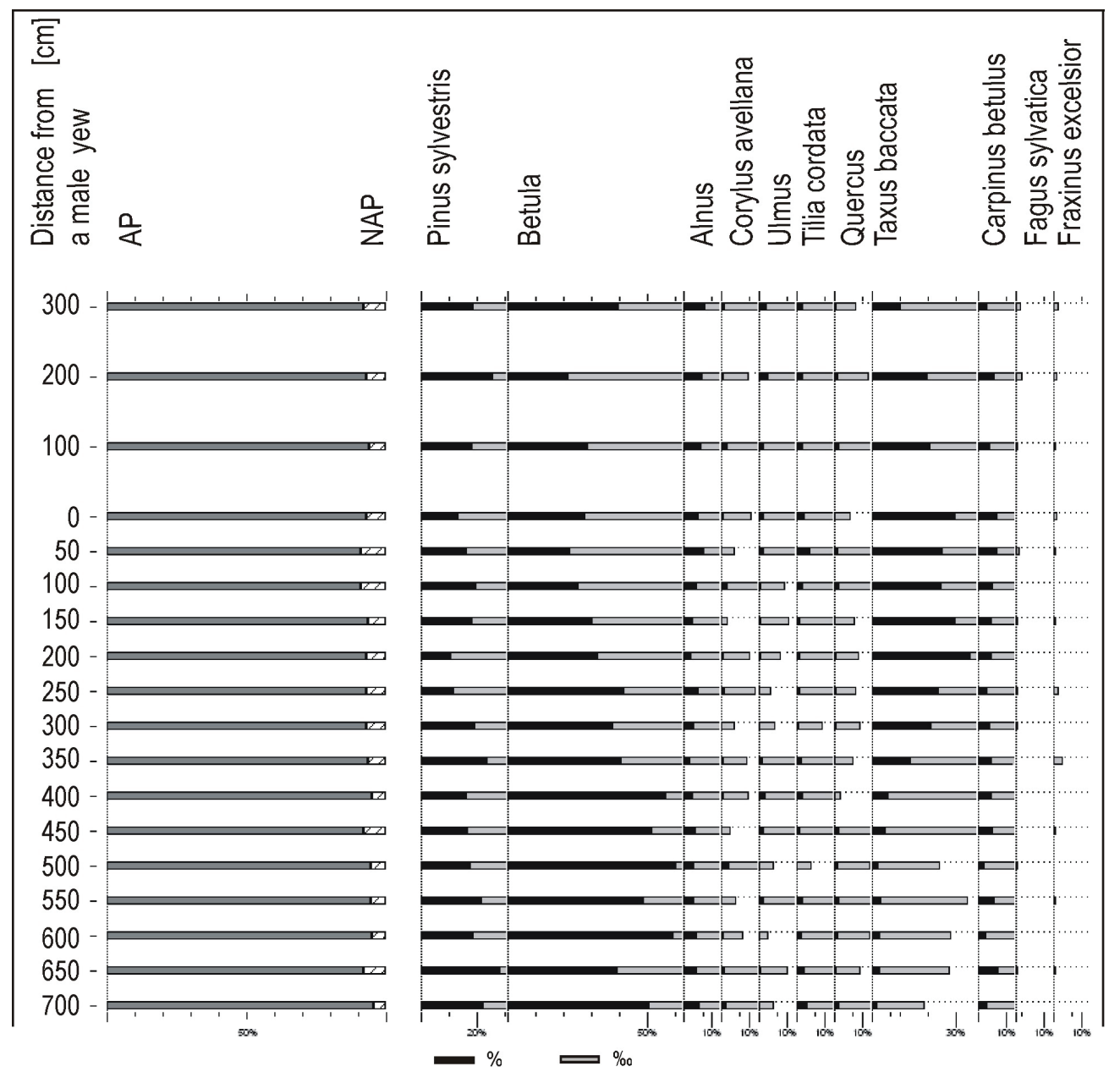

Figure 7. Wierzchlas; Surface samples in the transect from under one male yew tree in the forest (site 13 in fig. 2) percentage pollen diagram selected major taxa. Location of the samples as in Figs. 2 and 3

Only in one year (2000) was the pollen accumulation rate distinctly higher than 2300 grains per $1 \mathrm{~cm}^{3}$ and percentage participation was $5.5 \%$. This particular year was good not only for Taxus. Similar changes were noted for Carpinus, Picea, Quercus and Acer (Noryśkiewicz 2012). The closest trees in the vegetation grow within 15 meters. There is a group of trees (Populus, Salix, Quercus, Betula) 50 meters north of the trap. From the north-west and east a field and a flower garden adjoins to this station. So there are same exotic taxa as well as high diversity and variability in herb taxa in this trap. Herbal vegetation is systematically cut. It could have an impact on the considerable fluctuations observed in the presence of these plants in pollen spectra from year to year.

Trap W2 is situated in the multispecies forest with the yew making the lower layer, under dense forest canopy. Because of lack of the light, herbal vegetation is rather modestly represented. The density of the forest canopy is reflected in the pollen spectra. The percentage values, as well as the influx values clearly show the domination of tree pollen. In vegetation, among the tree species, most commonly represented are Taxus, Carpinus and Tilia but there are also Alnus and Pinus. The percentage values as well as the influx values show the domination of Taxus, Carpinus and Pinus. Taxus and Carpinus are local taxa but a third one - pine is rather from a long distance. Again, the 2000 season was the best year. The highest pollen influx was noted for the majority of the trees (especially Pinus, Carpinus and Taxus). Pollen of Secale cereale, Cerealia type, Rumex and Plantago lanceolata can be considered to have a long-distance origin, since they are cultivated several hundred meters from the trap.

On the edge of the mixed, humid (damp) forest with the yew in a lower layer was situated the trap W3. In the nearest vicinity of this trap there are Carpinus, Acer, Alnus, Taxus, Betula and Fraxinus. In the pollen spectra, there 
is domination of trees, especially, Taxus, Betula and Alnus. Pinus grains are of long-distance origin as there are no pine trees in the local area. Some old pines still grow in the Wierzchlas reserve but each year less, because every pine is about 300 years old. Among the herbal vegetation in the pollen spectra, most common are Poaceae much the same as the observed vegetation around the trap. As in the W2 trap Cerealia type and Rumex pollen are present, but the producers were absent in the surrounding area.

The trap W4 was placed in tussock-sedge swamp (Caricetum appropinquatae) surrounded by multi-species forests with yew. The percentage values, as well as the influx values show the domination of Cyperaceae. The most common tree taxa in the pollen spectra are Pinus, Betula and Alnus. In the trap from an open area but located so close to a large cluster of Taxus, percentage participation and influx of pollen of the yew is low. The representation of yew obtained is consistent with the results obtained from surface samples of semi-liquid lake sediments.

Comparison of the results obtained for all four traps (W1-4) allowed identification of some similarities. The Taxus influx was especially high at all Tauber site in the year 2000. Weather conditions have a significant influence on the fluctuations of the influx values of specific taxa. Based on the pollen data of Wierzchlas, it can be seen that the 2000 season was the best time for a pollen production. The meteorological data show that it was the hottest year in Poland during the last fifty years with extremely high average monthly temperatures for February, March and April (Kożuchowski \& Żmudzka 2002).

The largest quantity of pollen grains deposited on $1 \mathrm{~cm}^{2}$ surface during one year was in the forested area trap (W2). Influx of AP was more then six times higher then influx of NAP in samples from the forested area. In contrast the influx of AP was three times lower then NAP in samples taken from an open areas. For each tree pollen type, the influx is higher at the site where the tree species dominate and lowest at the site furthest from where the species are most abundant.

Large fluctuations in the pollen influx values were seen in the forested area. The smallest fluctuations in the pollen influx values were observed in the unforested area traps (W1 and W4).

To obtain comparable data for Tauber traps and lake sediments, the long-term averages for annual pollen deposition were calculated (Fig. 8).

\section{Conclusion}

The recent pollen investigations of fossil sediments from Wierzchlas indicate that Taxus baccata may be native from the beginning of the Subboreal (Fig. 5, 8). The strong representation of yew occurred already in the historic times and seems to reflect the selective yew protection originally conducted in this area or even planting the yew here. Yew pollen almost disappears in the W8a/W8b (Qu-Ca/Qu-Po, Fig. 4) and W8b (Qu-Po, Fig. 4) LPASZ. This can, however, result from the increased cutting of the tree for economic reasons by people in the Early Iron Age. However very low participation of the yew in the pollen diagrams from Mukrz Lake limits its value as an indicator of human activity.

The presence of yew pollen in the surface spectra from the reserve in Wierzchlas depends, thus, on both the distance between the samples and the male yew trees as well as the forest density. The comparison of the surface spectra from different habitats of this reserve (lake, forest floor and peatbog) and annual material from Tauber's traps reflected a big discrepancy in the representation of yew. These differences depend on both the habitat from which the material originated, and the distance of the sampling point from the male yew tree. The highest percentage of yew is noted in the samples originating from the Tilio-Carpinetum assemblage and the lowest percentage in alder forests and on a swamp which corresponds to the absence of the yew in these plant assemblages.

The differences which appears in the samples taken within the Tilio-Carpinetum assemblage, are mainly the reflection of a different distances from the male yew tree. The thesis of limited dissemination capability of the yew pollen is confirmed in the light of the results achieved. A considerable amount of the Taxus pollen was recorded only in the surface samples taken from the area close to the male specimens of yew trees.

Annual monitoring of pollen deposition using pollen traps facilitated the interpretation of local and regional presence of yew in the Wierzchlas during the Holocene (Fig. 8).

The results of the pollen analysis of surface samples and modern pollen traps from Wierzchlas suggest that the dispersal of yew pollen beyond the area of the forest was difficult in the conditions present in reserve (high density of trees) (Fig. 9). This research should help to clarify the history of the yew stand within this area and lead to the conclusion that even a low percentage of the yew pollen in the fossil diagram results from its presence in the forests at that time. However, it is difficult to estimate its representation in the forest quantitatively.

The main conclusion of the research in the reserve shows that Taxus baccata is strongly under-represented in the pollen diagrams, not only due to the difficulties in its identification (Krupiński et al. 2004) but also as a result of its limited dispersal. 


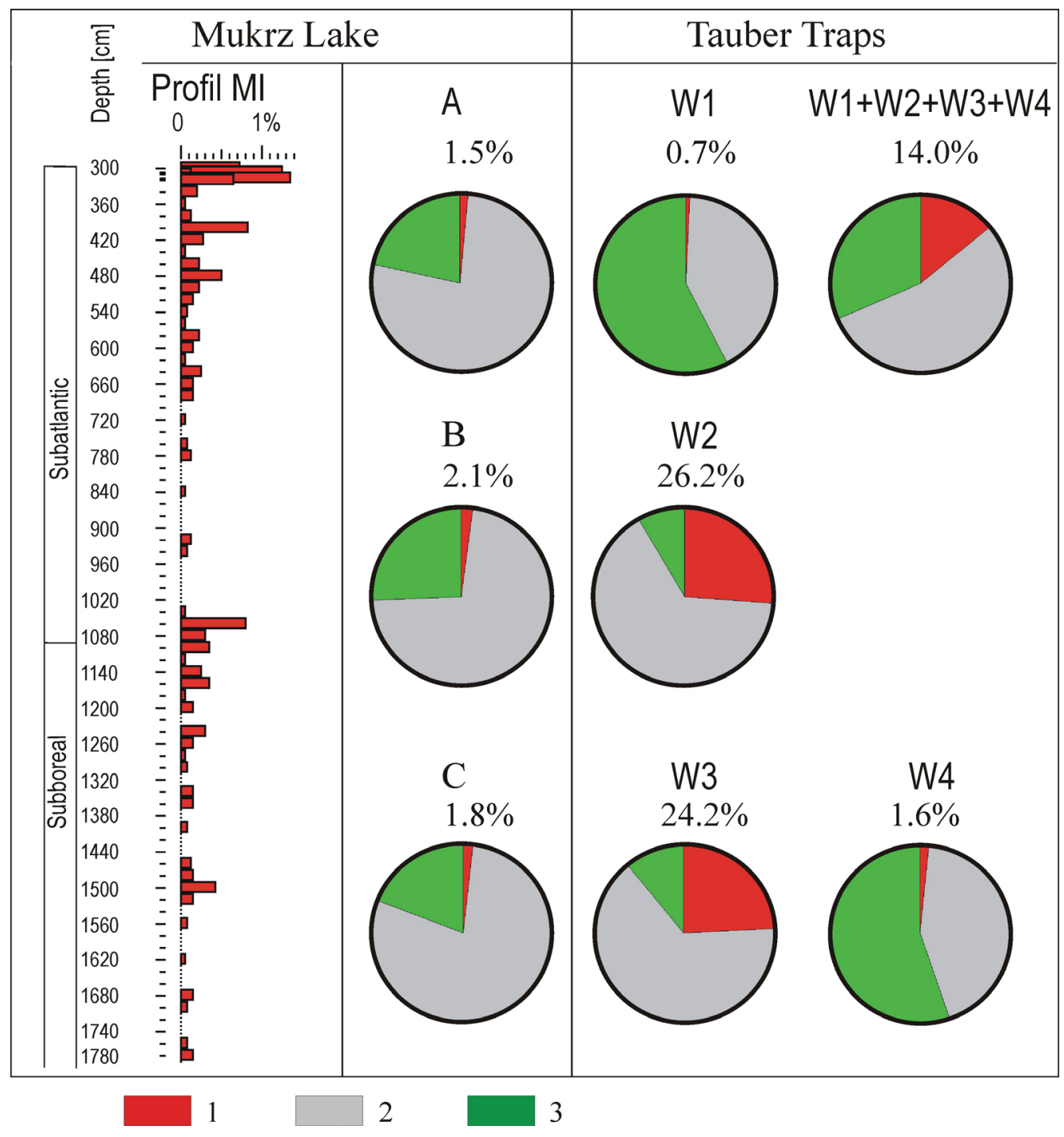

Figure 8. Wierzchlas; Percentage pollen participation of Taxus baccata in fossil deposits from Mukrz Lake and Tauber traps (for Tauber traps average values for the entire period of the study; 1998-2013); 1 - yew pollen, 2 - the rest AP pollen, 3 - NAP. Explanation of letters as in Fig. 1

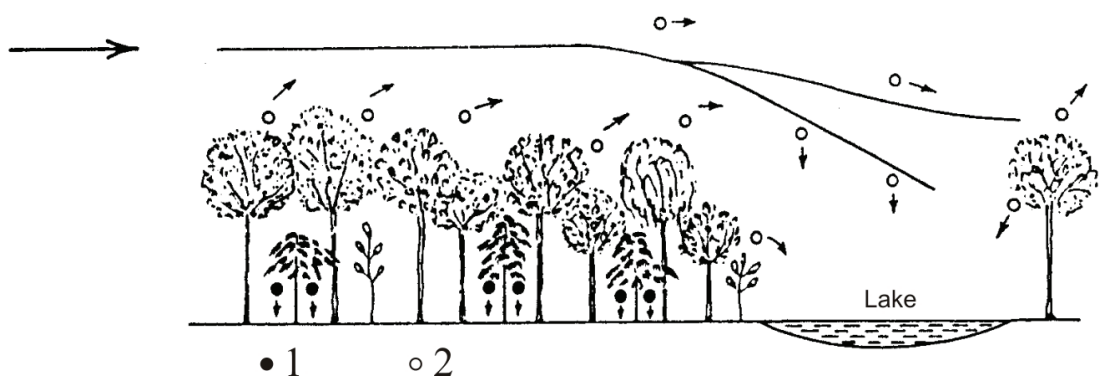

Figure 9. Presumable schema of dispersion in the Wierzchlas area of yew pollen: 1 - yew pollen; 2 - the rest AP pollen (drown by K. Czetwertyńska) 


\section{References}

Berglund B.E. \& Ralska-Jasiewiczowa M., 1986, Pollen analysis and pollen diagrams, [in:] Handbook of Holocene Palaeoecology and Palaeohydrology, B.E. Berglund (ed), Chichester: 455-484.

Boiński M., 1997, Rezerwat Przyrody „Cisy Staropolskie” im. Leona Wyczółkowskiego w Wierzchlesie [Nature Reserve of the Leon Wyczółkowski „The Old Polish Yews" in Wierzchlas], Towarzystwo Miłośników Borów Tucholskich, Bydgoszcz.

Hicks S., Ammann B., Latałowa M. \& Pardoe H., 1996, European pollen monitoring programme. Project description and guidelines. Oulu University.

Kożuchowski K. \& Żmudzka E., 2001, Ocieplenie w Polsce: Skala i rozkład sezonowy zmian temperatury powietrza w drugiej połowie XX wieku [The warming in Poland: the range and seasonality of the changes in air temperature in the second half of 20 th century], Przegl. Gofiz. XLVI (1-2): 81-90.

Krupiński K.K., Noryśkiewicz A.M. \& Nalepka, D., 2004, Taxus baccata L.Yew. [in:] Late Glacial and Holocene history of vegetation in Poland based on isopollen maps, M. Ralska-Jasiewiczowa, M. Latałowa, K. Wasylikowa, K. Tobolski, E. Madeyska, H.E. Jr. Wright, Ch. Turner (eds). Instytut Botaniki im. W. Szafera PAN, Kraków: 209-216.

Noryśkiewicz A.M., 1997, Analiza palinologiczna ściółki leśnej rezerwatu „Cisy Staropolskie im. Leona Wyczółkowskiego" w Wierzchlesie [Palynological analysis of forest litter of the Leon Wyczółkowski Nature Reserve „The Old Polish Yews” in Wierzchlas], [in:] Ochrona gatunkowa na obszarach chronionych [Species protection on protected areas], E. Krasicka-
Korczyńska (ed), Towarzystwo Miłośników Borów Tucholskich, Bydgoszcz: 55-61.

Noryśkiewicz A.M., 2001, mscr. IA NCU in Toruń, Historia cisa we Wierzchlesie na tle rozwoju postglacjalnej roślinności [The history of yew in Wierzchlas on the background of postglacial history of vegetation], UAM, Poznań.

Noryśkiewicz A.M., 2006, The history of the yew in the Wierzchlas in light of palynological research (in Polish with English summary). TPDW\& UMK Press, Toruń.

Noryśkiewicz A.M., 2012, Jedenaście lat monitoringu pyłkowego w rezerwacie Cisy Staropolskie im. L. Wyczółkowskiego [Eleven years of pollen monitoring in the L. Wyczółkowski Cisy Staropolskie Nature Reserve] (in Polish with English summary), [in:] Rezerwat przyrody "Cisy Staropolskie im. Leona Wyczółkowskiego” w Wierzchlesie, J. Pająkowski (ed), TPDW, Świecie: 21-31.

Stockmarr J., 1971, Tablets with spores in absolute pollen analysis, Pollen et Spores 13 (4): 615-621.

Tobolski K., 2002, Pomijana tematyka badawcza rezerwatu "Cisy Staropolskie im. L. Wyczółkowskiego" koło Wierzchlasu [Omitted research topics of the Leon Wyczółkowski „Cisy Staropolskie” [Ancient Polish Yew-Tree] Reserve near Wierzchlas], [in:] Park Narodowy Bory Tucholskie na tle projektowanego rezerwatu biosfery [Bory Tucholskie National Park in the concept of Biosphere Reserve], J. Banaszak, K. Tobolski (ed), Charzykowy: 165-194.

Więckowski K., 1970, New type of lightweight piston core sampler, Bulletin de l'Academie Polonaise des Sciences, Series Geological 18: 57-62.

Zając A., Zając M., 2001, Distribution Atlas of Vascular Plants in Poland. Jagiellonian University, Kraków. 